\title{
ON THE SEASONAL ABUNDANCE OF YOUNG FISH. VIII. THE YEAR I946, JUNE TO DECEMBER
}

\author{
By F. S. Russell, F.R.S. \\ Director of the Plymouth Laboratory
}

(Text-figs. I-3)

During the years $1930-9$ a series of records was obtained on the abundance of pelagic young of teleostean fish occurring in standard half-hour oblique hauls made with the $2 \mathrm{~m}$. stramin ringtrawl in the neighbourhood of the Eddystone. These results provided a record by which the composition of the young fish populations could be compared from year to year and any marked changes brought to notice. During the course of the observations there had been a striking reduction in abundance of young fish, and this had been correlated with the movements of water masses as indicated by certain plankton animals. The series of observations was brought to a conclusion in August I939 on the outbreak of war. The earliest opportunity after the cessation of hostilities has been taken to continue these observations on young fish, and collecting was started in June 1946 when a research ship was once more available. There has thus been a gap of nearly seven years during which there has been no detailed information on the conditions in the waters off Plymouth. The 1946 collections were started too late to include the main period of abundance of young fish resulting from the spring spawners, but they afford evidence that as regards the summer spawners at any rate there is no significant change from the conditions existing in 1939. We cannot say what the conditions have been during the intervening years, but analyses of phosphorus content of the water during each of the winters in the period I939-46 tend to show that conditions have remained much as they are at present, and that it is unlikely that there has been any large incursion of the rich water characterized by Sagitta elegans which supports a large population of young fish.

The dates on which collections were made are given in Table I, and the average monthly catches for each month from June to December 1946 are given in Table II; the fortnightly averages of all young fish less clupeids are shown in Fig. I. A comparison of the average monthly figures with those given in the corresponding table in the report for 1939 (Russell, I940) shows very close similarity. All species of summer spawning fish were very poorly represented, the only fish which were at any time at all numerous being Callionymus, Ctenolabrus rupestris and Blennius gattorugine. The high monthly average in July is due to these latter species which were abundant in the first two weeks of the month.

Records have at the same time been kept of the plankton animals in the catches (Figs. 2, 3). Throughout the period there has been a paucity of 


\section{TABle I. Dates ON Which COllections WeRE MADE, I946}

All 2 miles east of Eddystone

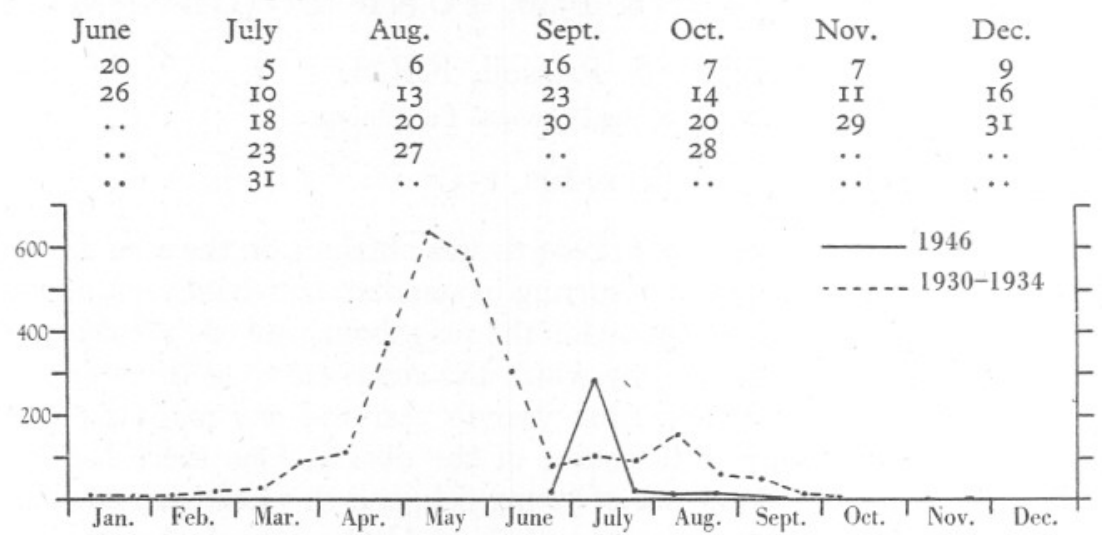

Fig. I. Curves showing the average catches in half-hour oblique hauls with the $2 \mathrm{~m}$. ringtrawl for each fortnight for all young fish, excluding clupeids, in I946 (June to December) ( - ), and the same averaged over the period 1930-4 inclusive (-----).

plankton and a predominance of Sagitta setosa, itself present only in small numbers. In late summer and autumn there was a large increase in numbers of Muggiaea which is normal for that time of year. The predominant species was $M$. atlantica, but it is noteworthy that in five of the collections in August and September a very small number of $M$. kochi were found, generally less than $\mathrm{I} \%$. This is the first time that the two species have been recorded together off Plymouth. Records kept by Dr Lebour during the war years have indicated that $M$. atlantica was present each year. This species has thus now been dominant at Plymouth since the winter of $1926^{1}$ when it replaced M. kochi. A few Liriope were caught in October and November 1946.

The occurrence of indicator species close inshore during the war as recorded by Lebour (1947) are tabulated below, Sagitta setosa being the prevailing Sagitta species during the period.

\begin{tabular}{|c|c|c|c|c|c|c|}
\hline & I940 & I94I & I942 & I943 & I944 & I945 \\
\hline Muggiaea atlantica & Aug.-Oct. & June-Dec. & $\begin{array}{c}\text { Jan., } \\
\text { Julv-Dec. }\end{array}$ & Apr.-Oct. & May-June & June-Nov. \\
\hline Ip a fusiformis & Aug. & - & - & - & - & - \\
\hline nomia bijuga & Aug. & 二 & $\overline{\mathrm{Aug}}$ & 二 & 二 & 二 \\
\hline itta elegans & 二 & Jan.-Feb. & - & May & - & Feb.-Ap \\
\hline
\end{tabular}

Pilchard eggs have been abundant in 1946, the catches on the different dates being as follows: June 20 (5510), 26 (21,700); July 5 (3820), I0 (4420), I8 (3740), 23 (2440), 3I (40); August 6 (400); September I6 (I4), 23 (228),

1 In Figs. 4, 3 and 4 of the reports for the years 1937,1938 and 1939 respectively, the year 1927 has inadvertently been substituted for 1926 in the legends. It was correctly given as I926 in the legend of Fig. 3 of the report for the year 1936. 
30 (7); October 7 (82), I4 (695), 20 (9I), 28 (5I); November 7 (830), II (25), 29 (20).

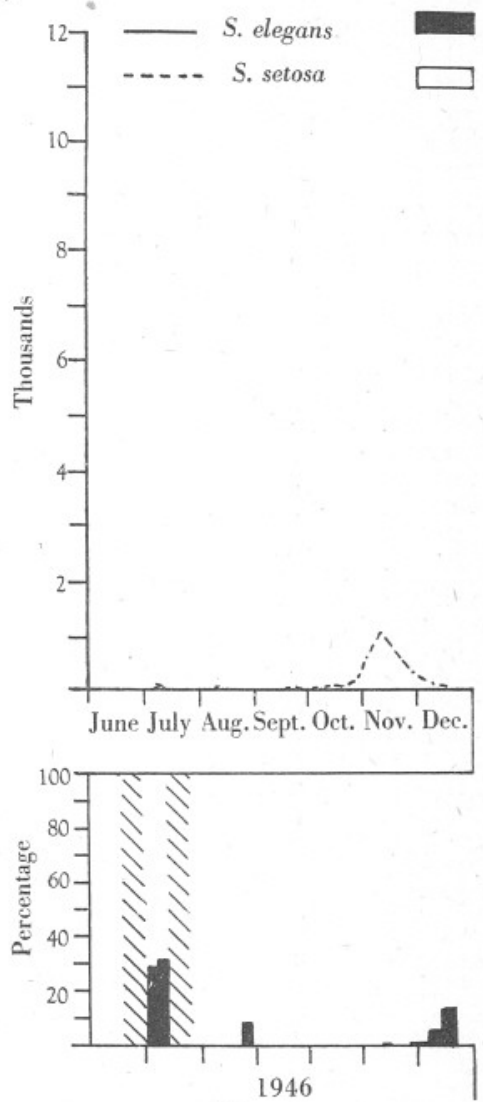

Fig. 2.

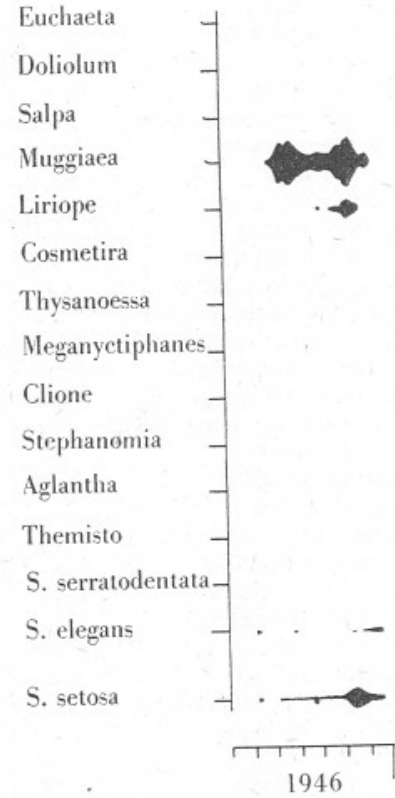

Fig. 3 .

Fig. 2. Above, curves showing the actual abundance of Sagitta elegans $(-)$ and S. setosa (---) in half-hour oblique hauls with the $2 \mathrm{~m}$. ringtrawl during the period June to December I946. Below, the percentage composition of the Sagitta populations during the same period: S. elegans, black; S. setosa, white; no Sagitta, hatched.

Fig. 3. Diagram showing the occurrence of the various plankton indicators in the collections off Plymouth during the period June to December I946. The Muggiaea species were practically entirely $M$. atlantica; a very small number of $M$. kochi occurred at times (see text).

It is noteworthy that in spite of the rest from fishing in the Channel during the war the numbers of pelagic young of summer spawners show no increase over those of the years just before the war.

\section{REFERENCES}

Lebour, Marie, V., I947. Notes on the inshore plankton of Plymouth. Fourn. Mar. Biol. Assoc., Vol. xxvi, pp. 527-47.

Russell, F. S., I940. On the seasonal abundance of young fish. VII. The year I939, January to August. Fourn. Mar. Biol. Assoc., Vol. xxiv, pp. 265-70. 


\section{Table II. Average Monthly Catches of Post-larvae Per Half-Hour}

Oblique hauls with $2 \mathrm{~m}$. ringtrawl, 1946

Total young fish

Ditto, less Clupeids

June July Aug. Sept. Oct. Nov. Dec. $\Sigma$

All Clupeid spp.

$\begin{array}{llllllll}35 & 190 & 39 & \ldots & 2 & 6 & 2 & 274\end{array}$

Clupea harengus

Gadus pollachius

Gadus merlangus

Gadus minutus

Gadus luscus

Gadus callarius

Onos spp.

Molva molva

Merluccius merluccius

Raniceps raninus

Capros aper

Zeus faber

Arnoglossus sp.

Rhombus maximus

Scophthalmus norvegicus

Zeugopterus punctatus

Zeugopterus unimaculatus

Pleuronectes limanda

Pleuronectes flesus

Pleuronectes microcephalus

Solea vulgaris

Solea variegata

Solea lascaris

Solea lutea

Serranus cabrilla

Caranx trachurus

Mullus surmulletus

Morone labrax

Ammodytes sp.

Ammodytes lanceolatus

Cepola rubescens

Callionymus sp.

Labrus bergylta

Labrus mixtus

Ctenolabrus rupestris

Crenilabrus melops

Centrolabrus exoletus

Trachinus vipera

Scomber scombrus

Gobius spp.

Lebetus scorpioides

Blennius ocellaris

Blennius pholis

Blennius gattorugine

Chirolophis galerita

Agonus cataphractus

Trigla spp.

Cottus sp.

Liparis montagui

Lepadogaster bimaculatus

Lophius piscatorius

Pipe fish

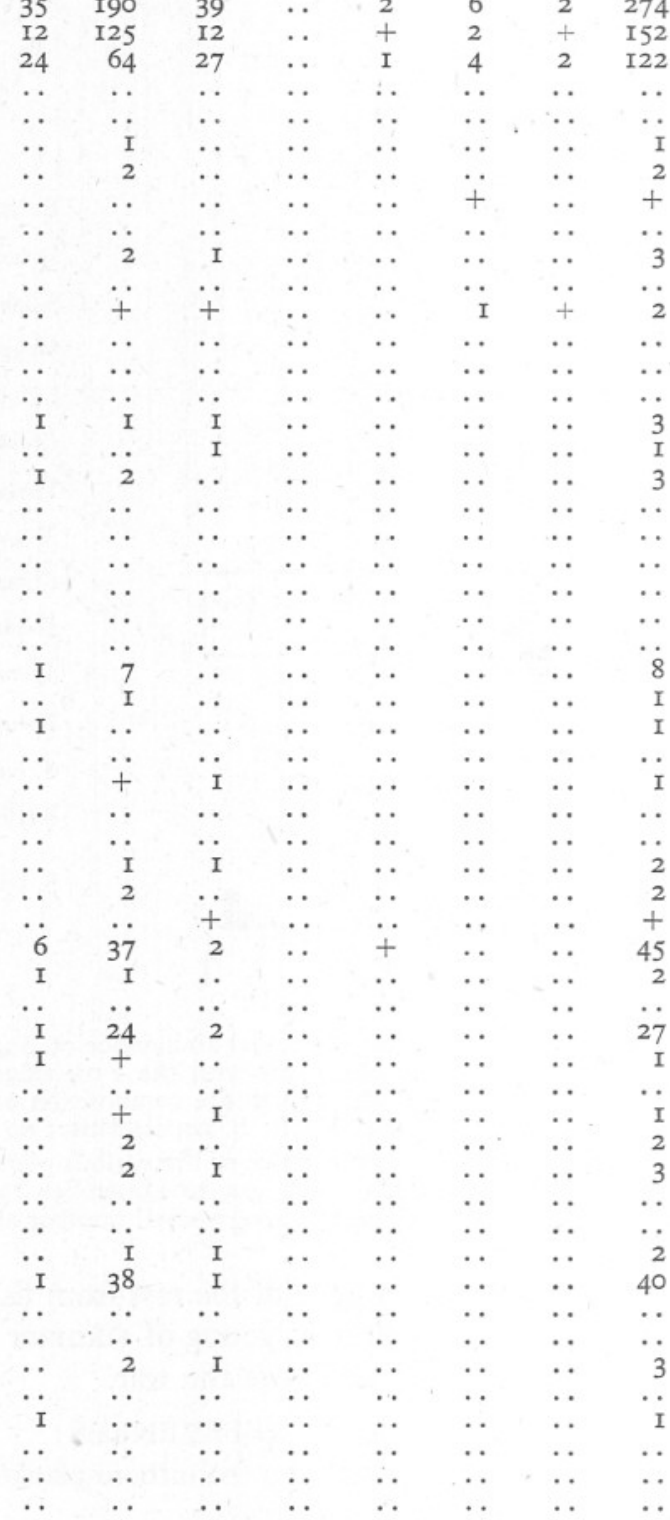

